\begin{tabular}{cc|c}
\hline Tar. Bil. Der. & Journal of Agricultural Sciences \\
& $\begin{array}{c}\text { Dergi web sayfası: } \\
\text { www.agri.ankara.edu.tr/dergi }\end{array}$ & Journal homepage: \\
& www.agri.ankara.edu.tr/journal
\end{tabular}

\title{
Changes of Electrophoretic Protein Profiles of Smoked and Marinated Rainbow Trout (Oncorhynchus mykiss) During Refrigerated Storage
}

\author{
Makbule BAYLAN ${ }^{a}$, Gamze MAZI ${ }^{a}$, Numan OZCAN $^{b}$, Bahri Devrim OZCAN ${ }^{c}$, Mustafa AKAR \\ Ali COSKUN ${ }^{b}$ \\ ${ }^{a}$ Çukurova University, Faculty of Fisheries, Department of Basic Sciences, Adana, TURKEY \\ ${ }^{b}$ Çukurova University, Faculty of Agriculture, Department of Animal Science, Adana, TURKEY \\ ${ }^{c}$ Osmaniye Korkut Ata University, Faculty of Arts and Sciences, Department of Biology, Osmaniye, TURKEY
}

\author{
ARTICAL INFO \\ Research Article DOI: 10.1501/Tarimbil_0000001328 \\ Corresponding author: Makbule BAYLAN, E-mail: makyan@cu.edu.tr, Tel:+90 (322) 3386084 \\ Received: 07 January 2014, Received in Revised Form: 15 July 2014, Accepted: 18 July 2014
}

\begin{abstract}
In this study, we aimed to determine the changes of electrophoretic protein profiles of smoked and marinated rainbow trout (Oncorhynchus mykiss) during refrigerated storage. Changes in muscle proteins during 9 weeks refrigerated storage of raw, smoked and marinated trout samples have been examined using sodium dodecyl sulphate polyacrylamide gel electrophoresis (SDS-PAGE). SDS-PAGE and densitometric analysis revealed that intensity and the number of some protein bands were reduced while the bands of actin didn't change significantly during marination and smoking of rainbow trout muscle. Myosin heavy chain (MHC) band with molecular weight of $205 \mathrm{kDa}$ disappeared in the $9^{\text {th }}$ week of smoking and marinating process. Subsequently, there were significant weekly changes in the protein percentages of samples caused by smoking and marinating processes $(\mathrm{P}<0.01)$. Protein percentages of the raw, smoked and marinated samples were determined as $18.34-18.82 \%, 23.83-24.70 \%$ and $16.29-17.76 \%$, respectively.
\end{abstract}

Keywords: Rainbow trout; Protein; SDS-PAGE; Smoking; Marinating

\section{Tütsülenmiş ve Marine Edilmiş Gökkuşağı Alabalığı (Oncorhynchus mykiss) Filetolarının Soğutulmuş Saklama Süresince Elektroforetik Protein Profilindeki Değișimler}

\section{ESER BILGISII}

Araştırma Makalesi

Sorumlu Yazar: Makbule BAYLAN, E-posta: makyan@cu.edu.tr, Tel:+90 (322) 3386084

Geliş Tarihi: 07 Ocak 2014, Düzeltmelerin Gelişi: 15 Temmuz 2014, Kabul: 18 Temmuz 2014

\section{ÖZET}

Bu çalışmayla, tütsülenmiş ve marine edilmiş gökkuşağı alabalığının (Oncorhynchus mykiss) buzdolabında depolama süresince elektroforetik protein profilindeki değişimlerin belirlenmesi amaçlanmıştır. Çiğg, tütsülenmiş ve marine edilmiş 
alabalık örneklerinin, 9 haftalık buzdolabında depolama süresince kas proteinlerindeki değişimler sodyum dodesil sülfat poliakrilamid jel elektroforezi (SDS-PAGE) kullanılarak incelenmiştir. SDS-PAGE ve densitometrik analiz sonuçlarına göre, tütsülenmiş ve marine edilmiş alabalık kaslarının, aktin bandlarında önemli bir değişimin olmadı̆̆ bazı protein banlarının sayısında ve yoğunluğunda bir azalmanın meydana geldiği gözlemlenmiştir. Depolamanın 9. haftasında, 205 kDa molekül ağırlığındaki myosin ağır zinciri (MHC), gözden kaybolmuştur. Ayrıca tütsülenmiş ve marine edilmiş örneklerin protein yüzdeleri de haftalık olarak önemli oranda değişim göstermiştir $(\mathrm{P}<0.01)$. Çi $\breve{g}$, tütsülenmiş ve marine edilmiş örneklerin protein yüzdeleri sırasıyla \% 18.34-18.82, \% 23.83-24.70 ve \% 16.29-17.76 aralıklarında bulunmuştur.

Anahtar Kelimeler: Gökkuşağı alabalığı; Protein; SDS-PAGE; Tütsüleme; Marinasyon

C Ankara Üniversitesi Ziraat Fakültesi

\section{Introduction}

Fishery products have an important place among processed foods both from health and taste aspects. They differ from other foods of animal origin due to the sensitivity to processing methods and storage and therefore, they easily lose their quality. In fact, fish proteins, especially myosin and collagen, are less stable than those in mammals (Poulter et al 1985). The changes in heat, $\mathrm{pH}$ and salt concentrations as well as diminishing agents denature proteins in fishery products like all other food proteins and they also destruct secondary and tertiary structures (Ledword 1979). It was reported that, aside the effect of salting, the crude protein content was concentrated by the methods of frying and smoking. Besides, after storage there was a reduction in crude protein content of the fried fish rather (Ayinsa \& Maalekuu 2011). Smoking and marinating are the oldest traditional fish preservation methods. There are many studies conducted about changes in physical, chemical, sensorial and microbiological quality of smoked and marinated fish products (Cosansu et al 2011; Kolodziejska et al 2002; Kilinc \& Cakli 2004; Basti et al 2006; Sallam et al 2007; Yanar 2007); however, there are only a limited number of studies investigating protein changes through electrophoretic methods.

It was reported that about $90 \%$ of fish proteins are generally denatured between $60-65{ }^{\circ} \mathrm{C}$, while the remaining $10 \%$ (tropomyosin) can remain stable without being denatured for a long time until $100{ }^{\circ} \mathrm{C}$ (Opstvedt et al 1984; Murueta et al 2007). Denaturing temperature might be affected by fish species, protein type and the ambient temperature (Opstvedt 1988).

It was argued that texture of fish meat changes not only with heat treatment but also with the effect of salt and acetic acid (Shimomura et al 1984; Shimomura \& Matsumoto 1985). Denatured proteins lose some of their physical and chemical properties. Indeed, Benjakul and Bauer (2000) stated that physicochemical and enzymatic properties of codfish muscle proteins are directly affected by the freezing and unfreezing cycles.

In a study investigating the protein loss of cuttlefish (Sepia officinalis L., 1758) salted with different methods, protein bands were not observed in the muscle tissue proteins of wet and dry salted samples at $205 \mathrm{kDa}$ and $35 \mathrm{kDa}$ intensities of SDSPAGE gel electrophoresis (Unlusayin et al 2001). In the cold smoked salmon fish samples, myosin heavy chain band density was observed to decrease with the increasing temperature and storage period (Hultman \& Rustad 2004).

It is known that most of the protein bands disappear due to hot smoking and denaturing in pike perch (Sander lucioperca L Kottelat 1997), rainbow trout (Oncorhynchus mykiss WALBAUM 1792) and eel (Anguilla anguilla L 1766) (Unlusayin et al 2001).

The purpose of this study, was to determine quality losses and the changes in proteins of rainbow trout preserved with marinating and smoking methods on SDS-PAGE during the storage period. 


\section{Material and Methods}

\subsection{Preparation of samples}

Rainbow trout samples were obtained fresh from local rainbow trout farm in Adana (Turkey), stored on ice insulated box and transferred to the laboratory. The mean length and weight of fishes (total 29 fish) were measured as $26.20 \pm 0.42 \mathrm{~cm}$ and $234.98 \pm 11.62 \mathrm{~g}$ respectively. Subsequently, the fish were beheaded, gutted, filleted and washed. Fillet samples were randomly divided into three groups: raw, smoking and marinating ( 9 fillets for each group). These processes were performed in duplicate. Crude protein contents (\%) were calculated using skinless samples.

\subsection{Raw samples}

For raw groups, filleted fish samples (1 fillet for each bags) placed in sterile vacuum bags (Baglight, Interscience, France) and then vacuumed by vacuum machine (Reepack, Model RV-50, Italy) without any treatment and these samples were stored at $+4{ }^{\circ} \mathrm{C}$ for 2 weeks.

\subsection{Smoking process}

Trout fillets were immersed in $20 \%$ of $1: 1$ (w $\mathrm{v}^{-1}$ ) brine solution at $4{ }^{\circ} \mathrm{C}$ for 1 hour. Smoke was produced from oak sawdust. All fillet samples were dried in heated smoking chamber at $90{ }^{\circ} \mathrm{C}$ for 60 min, smoked at $80{ }^{\circ} \mathrm{C}$ for $60 \mathrm{~min}$. Smoked fillets were cooled at ambient temperature for $30 \mathrm{~min}$. Then, fillets were placed in sterile bags (Baglight, Interscience, France). The fillets were vacuumed by vacuum machine (Reepack, Model RV-50, Italy) and stored at $+4{ }^{\circ} \mathrm{C}$ for 9 weeks (Küçükgülmez et al 2010).

\subsection{Marinating process}

Trout fillets were submerged into the marinating solution. As marinating solution, 3\% $\left(\mathrm{v} \mathrm{v} \mathrm{v}^{-1}\right)$ acetic acid and $10 \%\left(\mathrm{w} \mathrm{V}^{-1}\right) \mathrm{NaCl}$ were used. Fillets were submerged in this solution at 1:1.5 (w:v) ratio and kept for 48 hours in a refrigerator $\left(4 \pm 1{ }^{\circ} \mathrm{C}\right)$ and at the end of this period, they were taken out of the solution and drained for $15 \mathrm{~min}$. Then fillets were placed in sterilebags (Baglight, Interscience, France). The fillets were vacuumed by vacuum machine (Reepack, Model RV-50, Italy) and stored at $+4{ }^{\circ} \mathrm{C}$ for 9 weeks (Küçükgülmez 2012).

\subsection{Protein analysis}

Crude protein content was calculated by converting the nitrogen content according to Kjeldahl's methods (AOAC 1990).

\subsection{Sodium dodecyl sulfate polyacrylamide gel electrophoresis (SDS-PAGE)}

Raw, smoked and marinated samples were stored at $+4{ }^{\circ} \mathrm{C}$ from 1 to 9 weeks. After the end of the each week, one each samples were removed from refrigerator and their proteins were prepared for SDS-PAGE. Protein patterns of weekly stored rainbow trout samples were determined by using SDS-PAGE analysis by known standards as $\mathrm{kDa}$ ( $\beta$-galactosidase 116.0, Bovine serum albumin 66.2, Ovalbumin 45.0, Lactate dehydrogenase 35.0, REase Bsp981 25.0, $\beta$-lactoglobulin 18.4, and Lysozyme 14.4).

Raw, smoked and marinated samples for electrophoresis were prepared by homogenizing 1 gr minced skinless samples. From each one of raw, smoked and marinated samples, $1 \mathrm{~g}$ of sample was taken and homogenized within $100 \mathrm{ml}$ cold $\left(\sim 5^{\circ} \mathrm{C}\right)$ distilled deionized water with an Ultraturrax (IKA, T25 basic, Germany) for $30 \mathrm{~s}$. Raw and marinated samples were diluted at 1:1 in buffer prepared for raw samples $4 \%\left(\mathrm{w} \mathrm{V}^{-1}\right)$ SDS, $0.125 \mathrm{M}$ tris, $\mathrm{pH} 6.8$, $20 \%\left(\mathrm{v} \mathrm{v}^{-1}\right)$ glycerol, $10 \%\left(\mathrm{v} \mathrm{v}^{-1}\right) \beta$-mercaptoethanol), while the smoked samples were diluted at 1:3 (w $\left.\mathrm{V}^{-1}\right)$ ratio with the buffer used for cooked samples (0.1 mM phenylmethylsulfonyl fluoride (PMSF), 10 Mm EDTA, 0.01\% sodium azide (w:v) (Xiong et al 2002; An et al 1988). Weekly prepared samples were kept at $-20^{\circ} \mathrm{C}$ and homogenized using an ultraturrax at room temperature for 1 minute after nine weeks. The samples were then centrifuged for $20 \mathrm{~min}$ at room temperature, the supernatants were collected. All raw, smoked and marinated homogenates and molecular weight standard (MW range 14.4-116.0 $\mathrm{kDa}$, Fermentas, SM0431) were diluted 1:2 $\left(\mathrm{v} \mathrm{v}^{-1}\right)$ 
with loading dye and then boiled in a water bath $\left(100{ }^{\circ} \mathrm{C}\right)$ for $3 \mathrm{~min}$ and loaded in each gel lane.

SDS-PAGE analysis was carried out according to the method of Laemmli (1970). This was done with a SE 250 Mighty Small II slab gel electrophoresis unit (Hoefer Scientific Instruments, San Francisco, CA,USA) using a 3\% ( $\left.\mathrm{w} \mathrm{v}^{-1}\right)$ acrylamide stacking gel and $10 \%\left(\mathrm{w} \mathrm{V}^{-1}\right)$ acrylamide resolving gel (Srinivasan et al 1997). After electrophoresis, the gels were stained for 1 hour with Coomassie brillant blue R250 dye $\left(0.2 \%\left(\mathrm{w} \mathrm{v}^{-1}\right)\right.$ Coomassie brillant blue, $50 \%\left(\mathrm{v} \mathrm{v}^{-1}\right)$ methanol, $10 \%\left(\mathrm{v} \mathrm{v}^{-1}\right)$ glacial acetic acid). Afterwards, removal of the residual stain on the surface of gels was done with a destaining solution. Finally, gels preserved in acetic acid 5\% $\left(\mathrm{v} \mathrm{v}^{-1}\right)$ methanol, $7 \%\left(\mathrm{v} \mathrm{v}^{-1}\right)$ glacial acetic acid) were photographed on a white illuminated desk in a dark room. Densitometric analysis of protein bands were performed with Image J 1.4 (Image Program 2008).

\subsection{Statistical analysis}

The protein quantities (\%) of weekly stored rainbow trout samples obtained in this study were subject to variance analysis (one-way ANOVA) using SPSS 9.0 Windows software, and the mean values of important variance sources were compared with Duncan's multiple range test at $\mathrm{P}=0.01$ significance level.

\section{Results and Discussion}

The SDS-PAGE pattern of total proteins from raw, smoked and marinated samples in Figure 1, Figure 3 and Figure 5, respectively. The pattern reveals multiple bands in the molecular weight range between 116.0 and $14.4 \mathrm{kDa}$. The band appearing at over the marker of $116.0 \mathrm{kDa}$ is myosin $(205 \mathrm{kDa})$ heavy chain and at $45 \mathrm{kDa}$ is actin components. The protein profiles by SDS-PAGE helps to understand the process of aggregation during cold-storage.

The protein profile assessed by SDS-PAGE showed no difference in protein patterns during the $1^{\text {st }}$ and $2^{\text {nd }}$ weeks in raw trout proteins cold-storage at $+4{ }^{\circ} \mathrm{C}$. Similarly, it wasn't observed any changes in actin and myosin bands, either (Figure 1, Figure 2).

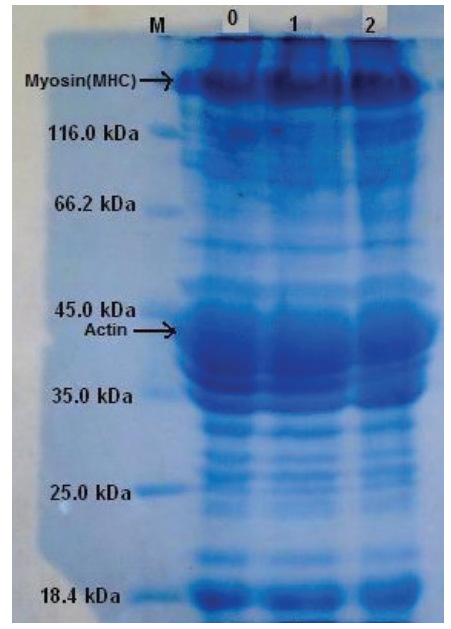

Figure 1- The comparison of total proteins of weekly stored $\left(+4{ }^{\circ} \mathrm{C}\right)$ raw rainbow trout samples in SDS-PAGE (M, marker; 0 , control; $1,1^{\text {st }}$ week; 2, $2^{\text {nd }}$ week)

Şekil 1- Haftalık depolanmış $\left(+4{ }^{\circ} \mathrm{C}\right)$ çĭ̆ gökkuşağ alabalık örneklerine ait toplam proteinlerin SDSPAGE'de karşılaştırılması (M, markır; 0,kontrol; 1, 1.hafta; 2, 2.hafta)

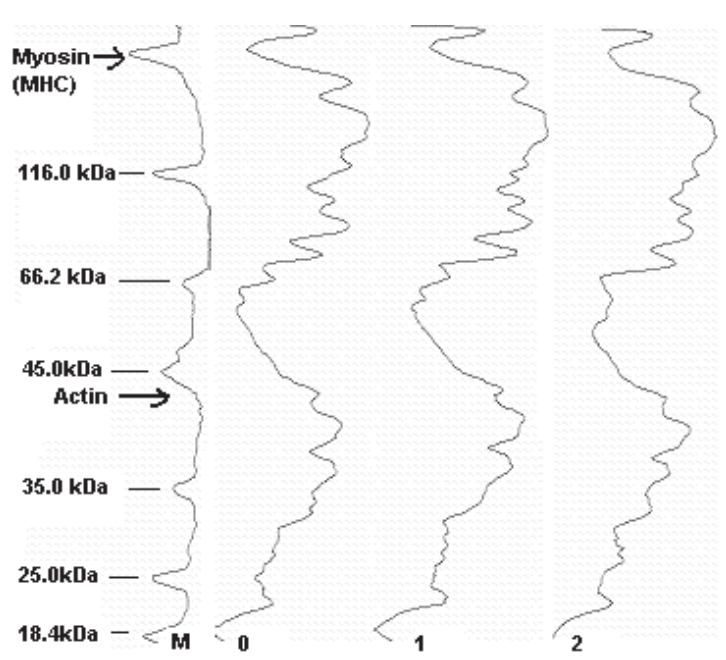

Figure 2- The densitometric analysis of protein bands of weekly stored $\left(+4{ }^{\circ} \mathrm{C}\right)$ raw rainbow trout (M, marker; 0 , control; $1,1^{\text {st }}$ week; $2,2^{\text {nd }}$ week)

Şekil 2- Haftalık depolanmış $\left(+4{ }^{\circ} \mathrm{C}\right)$ çiğ gökkuşağ alabalık örneklerine ait protein bandlarınin densitometrik analizi (M, markir; 0,kontrol; 1, 1.hafta; 2, 2.hafta) 
When the changes in proteins were investigated for the weekly stored $\left(+4{ }^{\circ} \mathrm{C}\right)$ and smoked rainbow trout for 9 weeks, it was determined that intensity of protein bands started to decrease from the $4^{\text {th }}$ to $7^{\text {th }}$ weeks, while some protein bands completely disappeared in the $8^{\text {th }}$ and $9^{\text {th }}$ weeks. In addition, there was an evident decrease in the intensity of actin and myosin bands in the later weeks (Figure 3 , Figure 4).

There was a significant difference $(\mathrm{P}<0.01)$ in protein quantity of samples by weeks storing at $+4{ }^{\circ} \mathrm{C}$. The crude protein content rainbow trout ranged between $18.34 \%$ (raw sample) to $26.10 \%$ for smoked samples. This increase could be attributed to applied salting and heat treatments. The protein content of the smoked fish product increased with salting and heat treatment because of decreasing water amount (Kolsarıcı ve Özkaya 1998).

In the marinated trout samples, muscle protein patterns showed a different profile during coldstorage marinated trout samples for 9 weeks (Figure 5, Figure 6).

The intensity of myosin and protein bands of over $116 \mathrm{kDa}$ molecular weight started to decrease as of the $3^{\text {rd }}$ week and degraded. Similarly, other muscle myofibrillar proteins started to degrade in the $2^{\text {nd }}$ and $3^{\text {rd }}$ weeks and some protein bands disappeared until the $9^{\text {th }}$ week. Similarly, Hernandez-Herrero et al (2000) investigated the protein changes with SDS-PAGE during the ripening process of the salted anchovy (Engraulis encrasicholus L.), and reported that fish muscle proteins demonstrated different profiles at different ripening periods. They also indicated that muscle myosin denatured in anchovy samples ripened with over $8-10 \%\left(\mathrm{w} \mathrm{v}^{-1}\right)$ salt, other myofibrillar muscle proteins partly denatured in anchovy samples ripened with over 15-16\% ( $\left.\mathrm{w} \mathrm{v}^{-1}\right)$ salt, while myofibrillar muscle proteins completely disappeared in anchovy samples ripened with over $20 \%\left(\mathrm{w} \mathrm{V}^{-1}\right)$ salt. Generally, actin is considered to remain stable with the processing of fish products. However, it remained constant until the $7^{\text {th }}$ week in our study, but gradually decreased afterwards. Michalczyk \& Surowka (2007) investigated the

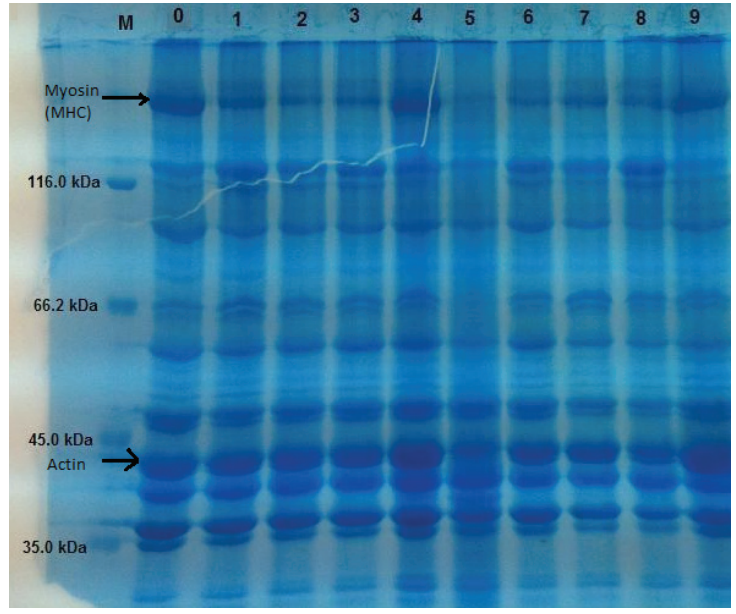

Figure 3- The comparison of total proteins of weekly stored $\left(+4^{\circ} \mathrm{C}\right)$ smoked rainbow trout samples in SDS-PAGE (M, marker; 0 , control; 1 , 1st week; 2 , $2^{\text {nd }}$ week; $3,3^{\text {rd }}$ week; $4,4^{\text {th }}$ week; $5,5^{\text {th }}$ week; $6,6^{\text {th }}$ week; $7,7^{\text {th }}$ week; $8,8^{\text {th }}$ week; $9,9^{\text {th }}$ week)

Şekil 3- Haftalık depolanmış $\left(+4{ }^{\circ} \mathrm{C}\right)$ tütsülenmiş gökkuşağl alabalı örneklerine ait toplam proteinlerin SDS-PAGE'de karşılaştırılması (M, markır; 0, kontrol; 1, 1.hafta; 2, 2.hafta; 3, 3.hafta; 4, 4. Hafta; 5, 5.hafta; 6, 6.hafta; 7, 7.hafta; 8, 8.hafta; 9, 9. hafta)

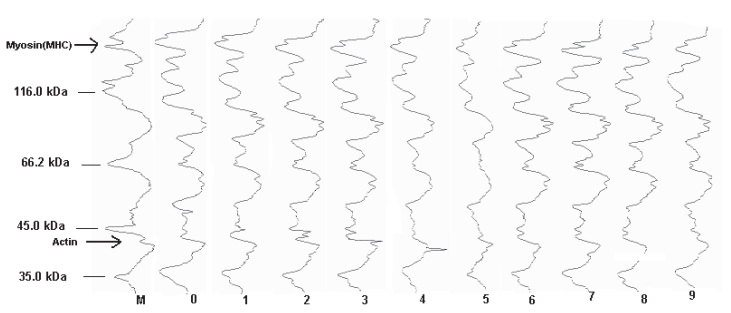

Figure 4- The densitometric analysis of protein bands of weekly stored $\left(+4^{\circ} \mathrm{C}\right)$ smoked rainbow trout (M, marker; 0 , control; 1 , 1st week; $2,2^{\text {nd }}$ week; $3,3^{\text {rd }}$ week; $4,4^{\text {th }}$ week; $5,5^{\text {th }}$ week; $6,6^{\text {th }}$ week; $7,7^{\text {th }}$ week; $8,8^{\text {th }}$ week; $9,9^{\text {th }}$ week)

Şekil 4- Haftalık depolanmış $\left(+4{ }^{\circ} \mathrm{C}\right)$ tütsülenmiş gökkuşağı alabalı örneklerine ait protein bandlarının densitometrik analizi ( $M$, markir; 0, kontrol; 1, 1.hafta; 2, 2.hafta; 3, 3.hafta; 4, 4. Hafta; 5, 5.hafta; 6, 6.hafta; 7, 7.hafta; 8, 8. hafta; 9, 9. hafta) 


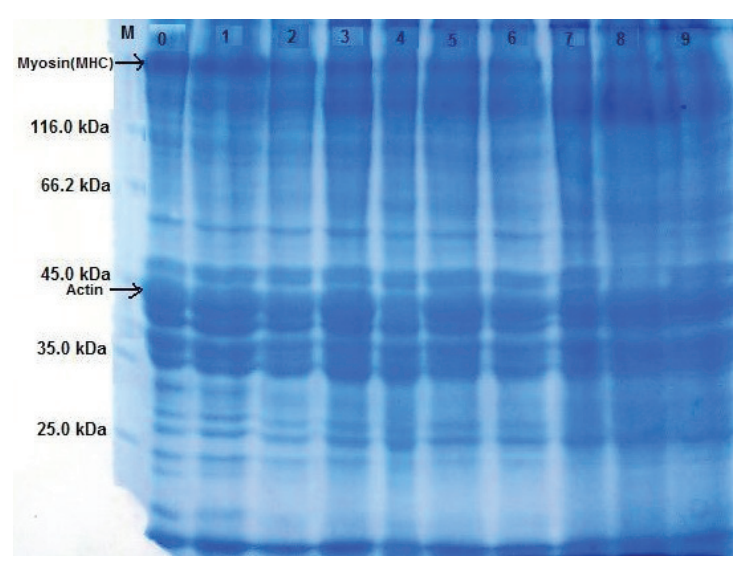

Figure 5- The comparison of total proteins of weekly stored $\left(+4{ }^{\circ} \mathrm{C}\right)$ marinated rainbow trout samples in SDS-PAGE (M, marker; 0 , control; 1 , 1st week; 2 , $2^{\text {nd }}$ week; $3,3^{\text {rd }}$ week; $4,4^{\text {th }}$ week; $5,5^{\text {th }}$ week; $6,6^{\text {th }}$ week; $7,7^{\text {th }}$ week; $8,8^{\text {th }}$ week; $9,9^{\text {th }}$ week)

Şekil 5-Haftalık depolanmış $\left(+4{ }^{\circ} \mathrm{C}\right)$ marine edilmiş gökkuşağı alabalık örneklerine ait toplam proteinlerin SDS-PAGE'de karşılaştırllması (M, markır; 0, kontrol; 1, 1.hafta; 2, 2.hafta; 3, 3.hafta; 4, 4. Hafta; 5, 5.hafta; 6, 6. hafta; 7, 7.hafta; 8, 8.hafta; 9, 9. hafta)

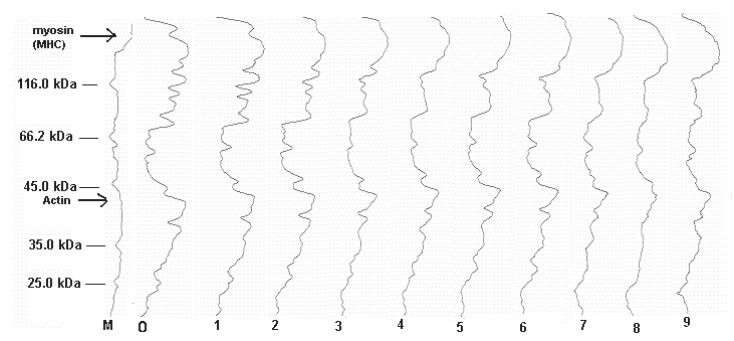

Figure 6- The densitometric analysis of protein bands of weekly stored $\left(+4^{\circ} \mathrm{C}\right)$ marinated rainbow trout $\left(\mathrm{M}\right.$, marker; 0 ,control; 1 , 1st week; $2,2^{\text {nd }}$ week; $3,3^{\text {rd }}$ week; $4,4^{\text {th }}$ week; $5,5^{\text {th }}$ week; $6,6^{\text {th }}$ week; $7,7^{\text {th }}$ week; $8,8^{\text {th }}$ week; $9,9^{\text {th }}$ week)

Şekil 6- Haftalık depolanmış $\left(+4{ }^{\circ} \mathrm{C}\right)$ marine edilmiş gökkuşağı alabalık örneklerine ait protein bandlarının densitometrik analizi ( $M$, markır; 0, kontrol; 1, 1.hafta; 2, 2.hafta; 3, 3.hafta; 4, 4. Hafta; 5, 5. hafta; 6, 6. hafta; 7, 7.hafta; 8, 8.hafta; 9, 9. hafta) type and scope of changes in rainbow trout gravad proteins during processing and vacuum storage at +3 ${ }^{\circ} \mathrm{C}$ and $-30{ }^{\circ} \mathrm{C}$. As a result of SDS-PAGE analysis, they determined that when gravads were cold stored for 8 weeks at an intensity of $274 \mathrm{kDa}, 160 \mathrm{kDa}$ bands and the C-protein increased compared to the fresh gravad. They showed that lowering of relative intensity of bands represents actin and myosin heavy chain. On the other hand, they stated that lowering actin and $\mathrm{MHC}$ bands could be due to their degradation caused by cathepsins. The crude protein content of rainbow trout ranged between $18.34 \%$ (raw sample) to $16.29 \%$ for marinated samples. This decrease could be attributed to proteolytic enzymes. Salting treatment decreased the protein of the marinated fish product as a result of protein being dissolved in the brine and other nitrogenous substance including free amino acids (Clucas \& Ward 1996).

Demir et al (2011) investigated molecular weights and band counts of sarcoplasmic proteins in four populations of Salmo trutta macrostigma living in Mediterranean Region of Turkey by using sodium dodecyl sulfate polyacrylamide gel electrophoresis (SDS-PAGE) method and densitometric analysis. Consequently, they found differences in molecular weights and number of bands in sarcoplasmic proteins of mountain trout (Salmo trutta macrostigma Dumeril 1858) samples collected from different populations. Similarly, Unlusayin et al (2010) investigated the effects of three different salting methods on rainbow trout and determined protein bands patterns by using SDSPAGE analysis with known mass standards. They visualized different bands on gels in fish belonging to different salting methods.

The statistical analysis of the crude protein changes demonstrated a significant difference $(\mathrm{P}<0.01)$ in the results of the crude protein $(\%)$ analysis of the weekly stored rainbow trout samples with smoking and marinating methods excluding raw materials. The protein quantities (\%) of weekly stored rainbow trout samples obtained in this study are given in Table 1. 
Table 1- Crude protein content $(\%)$ of stored $(+4$ ${ }^{\circ}$ C) rainbow trout

Çizelge 1- Depolanmış $\left(+4^{\circ} \mathrm{C}\right)$ gökkuşağı alabalık'ın ham protein içeriği (\%)

\begin{tabular}{lccc}
\hline Weeks & \multicolumn{2}{c}{ Protein (\%) } \\
\cline { 2 - 4 } & Raw & Smoked & Marinated \\
\hline 1 & $18.34 \pm 0.14^{\mathrm{a}}$ & $23.83 \pm 0.65^{\mathrm{a}}$ & $17.65 \pm 0.09^{\mathrm{a}}$ \\
2 & $18.82 \pm 0.13^{\mathrm{a}}$ & $24.70 \pm 0.07^{\mathrm{d}}$ & $17.62 \pm 0.07^{\mathrm{a}}$ \\
3 & $18.48 \pm 0.34^{\mathrm{a}}$ & $24.78 \pm 0.16^{\mathrm{d}}$ & $16.46 \pm 0.38^{\mathrm{c}}$ \\
4 & & $25.03 \pm 0.85^{\mathrm{d}}$ & $17.59 \pm 0.07^{\mathrm{c}}$ \\
5 & & $24.84 \pm 0.23^{\mathrm{d}}$ & $17.40 \pm 0.32^{\mathrm{ab}}$ \\
6 & & $25.40 \pm 0.28^{\mathrm{bcd}}$ & $16.29 \pm 0.10^{\mathrm{c}}$ \\
7 & & $25.00 \pm 0.05^{\mathrm{d}}$ & $17.36 \pm 0.30^{\mathrm{ab}}$ \\
8 & & $25.96 \pm 0.06^{\mathrm{bc}}$ & $17.51 \pm 0.30^{\mathrm{a}}$ \\
9 & & $25.27 \pm 0.05^{\mathrm{cd}}$ & $17.76 \pm 0.04^{\mathrm{a}}$
\end{tabular}

*, the variation between values shown with different letters in the same column is significant $(\mathrm{P}<0.01)$

Protein percentages of the raw, smoked and marinated samples were determined as 18.34$18.82 \%, \quad 23.83-24.70 \%$ and $16.29-17.76 \%$, respectively. It was reported that, aside the effect of salting, the crude protein content was concentrated by the methods of frying and smoking. Besides, after storage there was a reduction in crude protein content of the fried fish rather (Ayinsa \& Maalekuu 2011). Similarly no significant change was detected in crude protein values in sea bass filets (Dicentrarchus labrax, L. 1758) in sunflower oil during storage at $4{ }^{\circ} \mathrm{C}$ (Alparslan et al 2013). On the other hand, in our study, Although crude protein changes of all samples were found significant $(\mathrm{P}<0.01)$, there was no significant difference between the protein percentages with storage time.

\section{Conclusions}

The results of the polyacrylamide gel electrophoresis (SDS-PAGE) and densitometric analysis demonstrated that band intensities started to decrease in the $2^{\text {nd }}$ week in marinated and smoked samples excluding raw samples and some protein bands were relatively reduced in the later weeks and even some bands completely disappeared. Consequently, intensity and number of protein bands is decreased with increasing storage time.

\section{Acknowledgements}

This work was supported by the Scientific Research Projects Commission of Cukurova University (SUF2007BAP9). We wish to thank Prof. Dr.Yasemen YANAR and Assoc. Prof. Dr. Aygül KÜÇÜKGÜLMEZ for comments that helped to improve the manuscript.

\section{References}

Alparslan Y, Baygar T, Hasanhocaoğlu H \& Metin C (2013). Effects of scale and skin on chemical and sensory quality of marinated sea bass filets (Dicentrarchus labrax, L. 1758) in sunflower oil during storage at $4{ }^{\circ} \mathrm{C}$. Emirates Journal of Food and Agriculture 25(7): 516-523

An H, Marshall M R, Otwell W S \& Wei C I (1988). Electrophoretic identification of raw and cooked shrimp using various protein extraction system. Journal of Food Science 53(2): 313-318

AOAC (1990). Official methods of analysis, $15^{\text {th }} \mathrm{ed}$. Association of the Offical Analtical Chemists, Washington, DC, USA

Ayinsa H K \& Maalekuu B K (2013). Effect of traditional fish processing methods on the proximate composition of red fish stored under ambient room conditions. American Journal of Food and Nutrition 3(3): 73-82

Basti A A, Misaghi A, Salehi T Z \& Kamkar A (2006). Bacterial pathogens in fresh, smoked and salted Iranian fish. Food Control 17(3): 183-188

Benjakul S \& Bauer F (2000). Physicochemical and enzymatic changes of cod muscle proteins subjected to different freze \pm thaw cycles. Journal of the Science of Food and Agriculture 80: 1143-1150

Clucas I J \& Ward A R (1996). Post-Harvest Fisheries Development: A guide to Handling, Preservation, Processing and Quality. Chathman Maritime, Kent ME44TB, United Kingdom

Cosansu S, Mol S, Ucok Alakavuk D \& Tosun Ş Y (2011). Effects of Pediococcus spp. on the Quality of VacuumPacked Horse Mackerel during Cold Storage. Tarım Bilimleri Dergisi- Journal of Agricultural Sciences 17: 59-66

Demir O, Günlü A, Küçük F, Gülle İ \& Gümüş E (2011). Analysis of sarcoplamic proteins in natural populations of mountain trout (Salmo trutta macrostigma Dumeril, 1858) with SDS-PAGE. African Journal of Biotechnology 10(55): 11758-11763 
Hernandez-Herrero M M, Roig-Sagues A X, LopezSabater E I, Rodriguez-Jerez J J \& Mora-Ventura M T (2000). SDS-PAGE of salted anchovies (Engraulis encrasicholus $L$ ) during the ripening process. European Food Research Technology 212: 26-30

Hultman L \& Rustad T (2004). Iced storage of Atlantic salmon (Salmo salar)-effects on endogenous enzymes and their impact on muscle proteins and texture. Food Chemistry 87: 31-42

Image Program (2008). ImageJ 1.4, http://imagej. software.informer.com/1.4

Kilinc B \& Cakli S (2004). Chemical, microbiological and sensory changes in thawed frozen fillets of sardine (Sardina pilchardus) during marination. Food Chemistry 88(2): 275-280

Kolodziejska I, Niecikowska C, Januszewska E \& Sikorski Z E (2002). The microbial and sensory quality of mackerel hot smoked in mild conditions. Lebensmittel-Wissenschaft Und-Technology-Food Science and Technology 35: 87-92

Kolsarıcı N \& Özkaya Ö (1998). Effect of Smoking Methods on Shelf-Life of Rainbow Trout (Salmo gairdneri), Turkish journal of Veterinary and Animal Science 22: 273-284

Küçükgülmez A, Kadak A E \& Celik M (2010). Fatty acid composition and sensory properties of Wels catfish (Silurus glanis) hot smoked with different sawdust materials. International Journal of Food Science and Technology 45: 2645-2649

Küçükgülmez A (2012). Effects of chitosan on the shelf life of marinated sardine (Sardina pilchardus) fillets during refrigerated storage. Italian Journal of Animal Science 11: e48

Laemmli U K (1970). Cleavage of structural proteins during the assembly of the head of bacteriophage T4. Nature 227: 680-685

Ledword D A (1979). Protein-polysaccharides interactions In, Blansshard, M.V. and Mitchell, J.R. (Eds): Polysaccharidesin Food. pp. 56-78, Butterwolih and Co. Ltd Sydney

Michalczyk M \& Surowka K (2007). Changes in protein fractions of rainbow trout (Oncorhynchus mykiss) gravads during production and storage. Food Chemistry 104: 1006-1013

Murueta J H C, Toro M A N \& Carreno F G (2007). Concentratesof fish protein from bycatch species produced by various drying processes. Food Chemistry 100: 705-711
Opstvedt J, Miller R, Hardy R W \& Spinelli J (1984). Heat-induced changes in sulfhydryl groups and disulfide bonds in fish protein and their effect on protein and amino acid digestibility in rainbow trout (Salmo gairneri). Journal of Agricultural and Food Chemistry 32: 929-935

Opstvedt J (1988). Influence of drying and smoking on protein quality. Fish Smoking and Drying, In, Burt J R (Ed): Elsevier Applied Science Publishers LTD, London and New York, pp. 41-53

Poulter R G, Ledward D A, Godber S, Hall G \& Rowlands B (1985). Heat stability of fish muscle proteins. Journal of Food Technology 20: 203-217

Sallam K I, Ahmed A M, Elgazzar M M \& Eldaly E A (2007). Chemical quality and sensory attributes of marinated Pacific saury (Cololabis saira) during vacuum-packaged storage at $4{ }^{\circ} \mathrm{C}$. Food Chemistry 102(4): 1061-1070

Shimomura M, Tsuneki E, Itabashi F \& Matsumoto J J (1984). Changes in texture and proteins of wahoo meat during marination. Cookery Science 17: 105-112

Shimomura M \& Matsumoto J J (1985). Changes in texture and proteins during acid-salt curing of mackerel meat. Nippon Suisan Gakkaishi 51: 583-591

Srinivasan S, Xiong Y L, Blanchard S P \& Tidwell J H (1997). Physicochemical changesin prawns (Macrobrachium rosenbergii) subjected to multiple freze-thaw cycles. Journal of Food Science 62: 123127

Unlusayin M, Erdilal R, Gümüş B \& Gülyavuz H (2010). The effects of different salting methods on extract loss from rainbow trout. Pakistan Veterinary Journal 30(3): 131-134

Unlusayin M, Kaleli S \& Gulyavuz H (2001). The determination of flesh productivity and protein compotents of some fish species after hot smoking. Journal of the Science of Food and Agriculture 81: 661-664

Xiong S, Xiong Y L, Blanchard S P, Wang B \& Tidwell J H (2002). Evalution of tenderness in prawns (Machrobrachium rosenbergii) marinated in various salt and acid solitions. International Journal of Food Science and Technology 37: 291-296

Yanar Y (2007). Quality changes of hot smoked catfish (Clarias gariepinus) during refrigerated storage. Journal of Muscle Foods 18(4): 391-400 